\title{
Study on English Teaching Mode of Higher Vocational College based on ESP
}

\author{
Lingjie Chen \\ Jiangxi Vocational College of Industry \& Engineering \\ clj_775@126.com
}

Keywords: ESP, Higher Vocational College, English Language Teaching

\begin{abstract}
The ESP is a kind of study is based on the different needs of language teaching and language learning theory, it is the college English teaching in our country, especially in the trend of the higher vocational English teaching. College English teaching reform based on the theory of the ESP factors mainly include the change of teaching ideas, teaching material selection, teachers' quality. In this paper, in order to explore the ESP theory under the background of higher vocational college English teaching reform ideas, so as to promote English teaching reform and development.
\end{abstract}

\section{Overview of ESP Teaching Research}

The rise of ESP teaching originated in the 1960s, and three reasons for the generation of ESP were summarized in the study by Hutchinson and Waters (1987).2. Language revolution;3. Attention to learners.Both the popularization of new technologies and the transformation of linguists from language study to language use have greatly promoted ESP's teaching research.

ESP refers to the communication needs of English learners in English teaching in order to meet the needs of English learners in the Specific workplace, academic or professional environment (Davies, et al. 2004), that is, English for Specific, a branch of the English language field, with strong pertinence and practicality. In 1964, Halliday's "The Linguistic Science and Language would", clearly put forward The concept and classification of ESP, namely civil servants, English police English, English, a judge, pharmacists, and nurses English English English agricultural experts, engineers and equipment division of English, in other words, ESP is associated with a specific profession disciplines of English. Therefore, ESP has two distinct characteristics: 1. It has a specific purpose and is applied to a specific occupational range; 2. Special content, that is, specialized content.

\section{Teaching Features Under the Guidance of ESP Teaching Philosophy}

Based on the above concept of ESP and two obvious characteristics, it is not difficult to see that the teaching concept of ESP is clear. ESP is not only an English teaching method, but also a part of English language, and more of a learning method, which is an English language learning method adapted to the needs of learners. Therefore, teaching under the guidance of ESP teaching philosophy is also highly targeted and practical, which is embodied in the following aspects:

First, from the perspective of learners, ESP learners are those who already have certain English skills and have mastered certain professional knowledge. They can be college students of higher grades or social personnel who have graduated from universities and have been engaged in related majors. Secondly, from the perspective of learning content, ESP's content is relatively professional, and English is used as a language medium to learn professional knowledge, so as to complete various tasks in a specific field. Third: from the perspective of learning purpose, the learning 
purpose of ESP is to learn specialized courses or specialized knowledge through English media.

\section{Current Situation and Difficulties of Higher Vocational English Teaching}

(1) Unreasonable teaching objectives

The current society prefers to judge the English ability of talents by written materials.For this reason, higher vocational colleges pay too much attention to the passing rate of English proficiency test or the application of the ability to promote the teaching goal has obvious short-term utility.And this kind of teaching goal intensifies the high school graduate's competition, also cannot reflect the higher vocational education characteristic, more does not accord with the social actual need.

(2) Problems concerning students

English teaching is student-centered, and the English foundation of students directly determines the quality of English teaching.However, higher vocational education is different from ordinary universities, and students are mostly from vocational or undergraduate students, so there is a big difference in the overall lower level of English.

(3) Unbalanced teacher structure

English teachers in higher vocational colleges are mainly English majors. Although they can complete the teaching task of common English knowledge, education in higher vocational colleges is relatively special. English teaching must be combined with professional teaching, and teachers should have certain practical experience in industrial English. At present, most senior high school English teachers lack industry background and English application ability in related industries, and cannot meet education requirements of senior high school English. Therefore, the teacher structure is unbalanced.

(4) The teaching methods are rather antiquated

As a result of short-term utilitarian teaching objectives, teachers still use teaching methods and contents centered on teaching materials, teachers and phonetic knowledge, which cannot create conditions for students' language practice and is not conducive to their language application ability. In addition, the material content homogenization, the serious lack of specialized pertinence.Even the teaching syllabus is directly scripted, which is equivalent to the ordinary undergraduate education and lacks the talent cultivation style of higher vocational education.

\section{Specific Measures to Apply ESP Theory to Higher Vocational English Teaching}

We should comprehensively improve the quality and ability of higher vocational teachers and gradually build up a professional English teacher team with excellent quality. The quality and ability of teachers determine the level of teaching quality. A high-level professional English teacher team is the fundamental guarantee to carry out ESP teaching. At present, professional English teachers in vocational colleges are basically held by ordinary English teachers. The biggest challenge is the lack of professional knowledge involved in teaching. To be an effective professional English teacher, "more experience, extra training, extraordinary efforts and innovative professional abilities are needed". Therefore, we should start with improving the professional knowledge of professional English teachers and constantly improve their own quality and innovation ability.

We should emphasize the reform of the teaching mode with students as the main body and teachers as the leading role, and strive to explore new ways and methods of professional English teaching so as to constantly improve the teaching effect. In order to change the old and dull current 
situation of some professional English teaching methods, we should establish a new teaching mode with students as the subject and teachers as the leading role. Teachers should flexibly adopt a variety of teaching methods such as heuristic, research and discussion to organize classroom teaching, carry out comprehensive training in listening, speaking, reading, writing and translating, fully mobilize the enthusiasm of students, and try their best to let students participate in classroom teaching, so as to improve the teaching effect.

We should strengthen the construction of professional English teaching materials and integrate English teaching materials in higher vocational colleges.Besides the basic knowledge, teaching materials should be selected and practiced to meet the needs of social development and the operability of classroom teaching. To strengthen ESP teaching material construction must be guided by correct linguistic theory and practical teaching syllabus.ESP teaching materials should be selected based on the evaluation system of relevant teaching materials, taking into account the specific requirements of using object, purpose, content and teaching method.

Deal with the relationship with basic English teaching.ESP teaching is a continuation of the basic English teaching or extension, is the language knowledge and skills development to a certain stage in the light of the actual need students to further develop the students' language ability is an important teaching link, as Wilkins (1976:19) points out, "after the ESP training students in, they will be engaged in the professional field than those who only accept ordinary English education students more accurate!Be more effective at networking.

\section{Conclusion}

With the increasing expansion of China's and international exchanges, economic globalization, scientific and technological integration, and the coming of the age of cultural diversity, special-purpose English teaching is bound to become the mainstream of English teaching in the 21st century. According to statistics, more than 85 percent of international academic papers are published or read in English, and major academic journals in various disciplines are mainly in English. Accompanied by raising the overall level of English in our country, the special use English teaching will be the development direction of higher vocational college English teaching, English for special purposes (more and more get the attention of people, English teaching is being made from pure language knowledge input to comprehensively develop comprehensive language application ability, teaching model will also be organic integration of foreign language learning and learning professional knowledge, professional curriculum is closely related to some professional category or field. Hold good ESP teaching in higher vocational English teaching, therefore, the location in the framework, namely the development stage of the localization of language courses, to better understand the teaching in the process of English professional talent training to achieve the teaching purpose and to realize the training effect, so as to find the effective teaching methods to promote the maturity and development of the course module, to ensure smooth implementation, compound talents for ESP connotation to extension, achieve the demand of market with the international community.

\section{References}

[1] Halliday M A K, Mclintosh A and Strevens P. The Linguistic Science and Language Teaching[M]. London: Longman, 1964.

[2] Hutchinson T, Waters A. English for Specific Purpose: A Learning-centered approach[M]. 
Cambridge: Cambridge University Press, 1987.

[3] CAI jigang.ESP and the development direction of college English teaching in China [J]. Foreign language field, 2004. (2)

[4] CAI jigang. Characteristics and countermeasures of college English teaching in China during the transition period [J]. Foreign language teaching and research, 2007,39

[5] Yin fulin. Reflections on ESP teaching evaluation system [J]. Journal of Shanghai university of technology. 2011, 3 